\begin{tabular}{lr}
\hline \multicolumn{1}{c}{ D Y N A M I C E C O N O M E T R I C } & M O D E L S \\
DOI: http://dx.doi.org/10.12775/DEM.2019.002 & Vol. 19 (2019) 29-40 \\
\hline $\begin{array}{l}\text { Submitted September 11, } 2019 \\
\text { Accepted December 17, 2019 }\end{array}$ & ISSN (online) 2450-7067 \\
ISSN (print) 1234-3862
\end{tabular}

Accepted December 17, 2019

ISSN (print) 1234-3862

\author{
Mitra Lal Devkota*
}

\title{
Impact of Export and Import on Economic Growth: Time Series Evidence from India
}

\begin{abstract}
A b s tra ct. This paper examines the cointegration and causal relationships between export, import, and economic growth in India using quarterly data from 1996:Q2 to 2019:Q2. Stationarity properties of the time series data are investigated using Augmented Dickey Fuller (ADF) and Phillips-Perron (PP) unit root tests, and the existence of cointegrating relationship is studied using Johansen's cointegration test. Finally, the causal relationships between the variables are examined using Vector Error Correction Model (VECM). The results show that, under both tests, the time series variables are non-stationary at their levels and are stationary at their first differences. The Johansen's cointegration test shows the existence of a long run equilibrium relationship among the variables. The results from the VECM indicate that there is a unidirectional causal relationship running from economic growth to import in India. This implies that with an increase in the income of the nation, the nation's spending will increase, and some of the spending will be on import.
\end{abstract}

K e y w o r d s: Export, Import, Gross Domestic Product, Causality, Cointegration, India

J E L Classification: C22; E00; E44

\section{Introduction}

Over the past several decades, there has been a great debate among the researchers on three hypotheses in trade and development literature. Some empirical studies (Michaely, 1977; Bhagwati, 1978; Balassa, 1978; Tang et

\footnotetext{
*Correspondence to Mitra Lal Devkota, University of North Georgia, Department of Management and Marketing, Mike Cottrell College of Business, 82 College Circle, Dahlonega, GA 30597, United States, e-mail: mldevkota@ung.edu

(C) 2019 Nicolaus Copernicus University. All rights reserved. http://www.dem.umk.pl/dem
} 
al., 2015, among others) argue in favor of Exports Led Growth (ELG) hypothesis, which states that exports make a significant contribution to economic growth of an economy (i.e. the flow of causality is from exports to economic growth). They claim that the countries exporting a large amount of their production grow more rapidly than others do. A number of empirical studies (Krugman, 1984; Bhagwati, 1988; Oxley, 1993; Sharma and Dhakal, 1994; Ghatak and Price, 1997, among others) have shown the possibility of Growth Led Exports (GLE) in which the flow of causality is from economic growth to exports. The third alternative is that of Imports Led Growth (ILG) in which the flow of causality is from imports to the economic growth (Awokuse, 2008). Growth in imports can help in transfer of growth, enhancing foreign trade research and development knowledge from developed to the developing countries (Mazumdar, 2001). However, the flow of causality depends on the time period of the data under study, frequency of the data such as monthly, quarterly, and yearly, and the methodology employed in the study.

This paper differs from the existing literature on the study of cointegration and causality relationships between export, import, and economic growth in India in several ways. First, the existing studies have used either annual or monthly time series data covering comparatively a shorter period of time (Guntukula, 2018; Jyoti Kumari, 2014). We have used quarterly time series data that cover a longer period of time period and include recent data (1996:Q2 to 2019:Q2). The study not including the recent data will not reflect the current economic development of the country. Second, most of these studies suffer from some weaknesses in the adopted methodologies. For instance, the Augmented Dickey Fuller (ADF) method used for testing the stationarity of the time series data is widely criticized for its low power and size properties. We have supplemented this by including Phillips Perron unit root test in addition to the ADF test. Phillips-Perron test is nonparametric, i.e., it does not require one to select the level of serial correlation as in ADF. In addition, the PhillipsPerron test is robust to general forms of heteroscedasticity in the error term and the user does not have to specify a lag length for the test in regression. Finally, to the best of our knowledge, no previous studies have employed the Granger causality test based on VECM framework to examine both short and long run causality relationships between export, import, and the economic growth in India. ${ }^{1}$ We tested the long run causality between the variables

\footnotetext{
${ }^{1}$ Some studies such as Mishra (2012) and Malhotra and Meenu (2009), among others, only study the impact of import on GDP, but exclude the impact of export on GDP. On the other hand, studies such as Guntukula (2018) study the impact of export and import on GDP, but fail to examine both short- and long-run causal relationships between the variables under VECM framework.
} 
through the statistical significance of the error correction term (ECT) by a ttest. On the other hand, we tested the short run causality through the significance of the lags of each explanatory variable by a Wald chi-squared test.

The rest of the paper is organized as follows. A review of previous empirical studies is carried out in section 1. A detailed description of the data and the variables used in the study are presented in section 2 . The econometric methodology used in the study and discussion of the empirical results are presented in section 3. The last section concludes the paper.

\section{Literature Review}

A number of time series and cross-sectional methodologies have been used for testing the causality and cointegration relationships between export, import, and economic growth. These studies have used data from both developed and developing countries. In this section, we review a selected number of empirical studies from a plethora of research articles in the area.

Alam, Uddin, and Taufique (2009) investigated the existence of gravity theory for the import of Bangladesh with its eight major trading partner countries India, China, Singapore, Japan, Hong Kong, South Korea, USA, and Malaysia using data from 1985 to 2003 in panel approach. They found that the gravity theory is consistent with the imports of Bangladesh, that is, the geographical distance of Bangladesh with its partner countries has significant impacts on its imports. They further document that the GDP of the major partner countries had significant positive impact on the import of Bangladesh, and that the population of these countries has a mixed impact on imports of Bangladesh.

Din (2004) investigated the export-led growth hypothesis for the five largest economies-Nepal, Bangladesh, India, Sri Lanka, and Pakistan of the South Asian region using a multivariate time-series framework. The author finds an interesting result in view of their increasing outward orientation and adoption of export promotion policies as part of their growth strategies in these South Asian countries. While controlling for imports, the results showed a bidirectional causality between exports and output growth in Bangladesh, India, and Sri Lanka in the short-run. The study also found long-run equilibrium relationships between exports, imports, and output growth for Bangladesh and Pakistan. However, the study found no evidence of a long-run relationship between the variables for India, Nepal, and Sri Lanka.

Kogid et. al (2011) investigated the causality and cointegration relationships between the economic growth and the import in Malaysia using annual 
time series data from 1970 to 2007 . Their results show no evidence of a cointegrating relationship between economic growth and import in Malaysia. However, they find the evidence of a bidirectional causality between the economic growth and import. They further document that import could indirectly contribute to economic growth, and economic growth could directly contribute to import.

Tagavhi (2012) investigated the relationship between export, import, and economic growth in Iran for the period between 1962 and 2011. The empirical results show the existence of a long run relationship between the variables under consideration. The results further show that, in the long run, export had positive relationship with economic growth, and import had a negative relationship with economic growth.

Guntukula (2018) investigated the relationships between export, import, and economic growth in India using monthly time series data from April 2005 to March 2017. The study found a long run relationship between export, import, and economic growth for the study period. The study also found the evidence of a bidirectional causality between exports and economic growth, and between imports and economic growth, confirming the existence of a bidirectional causality between exports and economic growth. Similarly, Jyoti Kumari (2014) investigated the relationship between export, import, and economic growth using annual data for India for the period post liberalization from 1991-92 to 2012-13. The author found that import must be supported by export to have continuous growth in the economy. She further documents that export has positive effect on economic growth by keeping import fixed, while import has negative effect on economic growth by keeping export fixed.

Ramos (2001) investigated the Granger causality between exports, imports, and economic growth in Portugal using annual data over the period 1865-1998. The empirical investigation finds no evidence of a unidirectional causality relation between export, import, and output growth. They found the evidence of feedback relationships between export and output growth and import and output growth. But they found no significant causality between import and export growth.

\section{Data}

Our analysis uses the seasonally adjusted quarterly time series data for India for the period between 1996:Q2 to 2019:Q2. The variables used in the study are real export, real import, and real GDP in local currency (i.e. Indian rupees), which are then expressed in natural logarithms. We have transformed 
the export, import and GDP into natural logarithms because this transformation is the most commonly used variance stabilizing tool for variables that have wide range (Weisberg, 1980). We take the gross domestic product (GDP) as the proxy for economic growth because GDP is essentially an indicator of aggregate economic activity of a country. These data are obtained from Economic research database of Federal Reserve Bank of St. Louis. Statistical software packages $\mathrm{R}$ and EViews are used for the econometric analyses of the data.

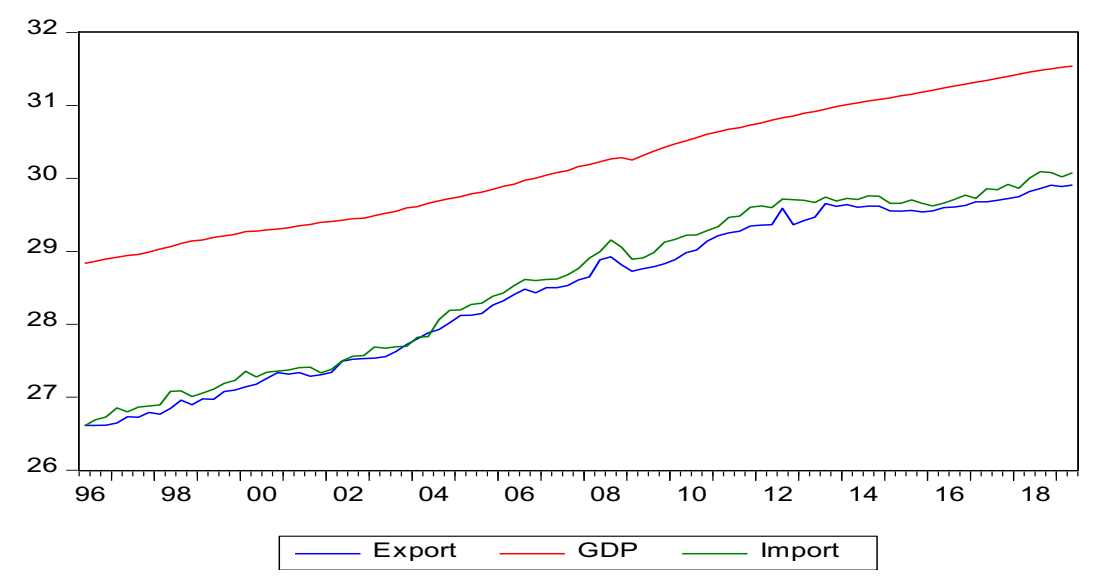

Figure 1. Export, Import and GDP for India:1996-2019

Table 1. Summary Statistics for export, import, and GDP

\begin{tabular}{cccc}
\hline & Export & Import & GDP \\
\cline { 2 - 4 } Min & 26.61 & 26.61 & 28.84 \\
1st Qu & 27.34 & 27.41 & 29.41 \\
Median & 28.61 & 28.77 & 30.16 \\
Mean & 28.44 & 28.58 & 30.18 \\
3rd Qu & 29.55 & 29.66 & 30.95 \\
Max & 29.91 & 30.09 & 31.54 \\
Std. Dev & 1.078 & 1.107 & 0.836 \\
Skewness & -0.262 & 0.063 & -0.268 \\
Kurtosis & 1.617 & 1.648 & 1.571 \\
Jarque-Bera p-value & 0.014 & 0.028 & 0.011 \\
\hline
\end{tabular}

Time series plots for the logarithmic values of export, import and GDP are shown in figure 1 . The plot indicates that the time series data for each of the variables have fairly strong upward trends. This gives anecdotal evidence that 
each of the time series data tend to move together. Summary statistics for export, import, and GDP indicate that these variables have means equal to 28.44 , $28.58,30.18$ with associated standard deviations of $1.078,1.107,0.836$, and coefficient of variation $0.0379,0.0387,0.0277$ respectively. The Jarque-Bera test statistic for each variable has a p-value greater than 0.01 . This implies that each of the variables' distributions are normal. This study includes the maximum range of the time series data available to the author available at the time of analysis.

\section{Methodology and Empirical Results}

Existence of cointegrating relationships and the directions of causalities (if any) between export, import and GDP can be decided only by empirical investigation. As such, we first study the time series properties of the data by using Augmented Dickey Fuller (ADF) and Phillips-Perron (PP) unit root tests. We then use Johansen's cointegration test to examine the existence of long run equilibrium relationship between the variables and to find the number of cointegrating vectors. Finally, we study the direction of causality and model the short and long run causal relationships between the variables by using Granger causality test under vector error correction model (VECM) framework.

\subsection{Unit Root Test for Testing Stationarity}

The initial step in the time series data analysis involves testing the presence of unit root of each of the variables. For this purpose, we have used Augmented Dickey Fuller unit root test (Dickey and Fuller; 1979, 1981) and Phillips-Perron unit root test (Phillips and Perron, 1988) at the levels and first differences of the variables.

Table 2. Unit Root Test Results

\begin{tabular}{clccc}
\hline \multirow{2}{*}{ Variable } & \multicolumn{2}{c}{ ADF-Test } & \multicolumn{2}{c}{ Phillips-Perron Test } \\
\cline { 2 - 5 } & \multicolumn{1}{c}{ Levels } & First Difference & Levels & First Difference \\
\hline GDP & $0.25[0.975]$ & $-8.01[0]^{*}$ & $0.17[0.970]$ & $-8.17[0]^{*}$ \\
Export & $-1.22[0.662]$ & $-10.66[0]^{*}$ & $-1.38[0.589]$ & $-10.74[0]^{*}$ \\
Import & $-1.45[0.553]$ & $-9.63[0]^{*}$ & $-1.59[0.483]$ & $-9.68[0]^{*}$ \\
\hline
\end{tabular}

Note: Given figures are the test statistics and their respective p-values are inside the brackets. * denotes the rejection of the null hypothesis of non-stationarity of the variables at $\alpha=0.01$ level of significance. 
The results of both the ADF test and PP test for the levels and first differences of the variables are shown in Table 2 . These results suggest that all the variables are non-stationary in their levels. However, the unit root test applied in the first difference of these variables indicate that each of the series is stationary in their first differences. Thus, we conclude that each of the export, import, and GDP are integrated of order one, i.e. I(1).

\subsection{Cointegration Analysis}

Once establishing the stationarity of the variables, we proceed to the next step of our analysis, which is to investigate the existence of long run equilibrium relationship between the variables and to determine the number of cointegrating vectors. For this, we employ the Johansen $(1988,1991,1992)$ and Johansen and Juselius (1990) maximum likelihood cointegration technique. This technique is based on Granger's (1981) ECM representation.

To determine the number of cointegrating vectors, we employed both the available likelihood ratio tests. These are trace test $(\lambda$-trace) and maximum eigenvalue test $(\lambda$-max). For both the directions, 1 lag was used (as determined by LRT, FPE, AIC, SIC, and HQ criteria). The results for both the trace test and maximum eigenvalue tests are reported in Table 3.

Table 3. Johansen Cointegration Test Results (Trace and max. eigenvalue)

\begin{tabular}{ccccccc}
\hline $\begin{array}{c}\text { Null Hy- } \\
\text { potheses }\end{array}$ & $\begin{array}{c}\lambda_{\text {trace }} \\
\text { Stat }\end{array}$ & $\begin{array}{c}5 \% \text { Critical } \\
\text { Value }\end{array}$ & p-value & $\begin{array}{c}\lambda_{\max } \\
\text { Stat }\end{array}$ & $\begin{array}{c}5 \% \text { Critical } \\
\text { Value }\end{array}$ & p-value \\
\hline $\mathrm{r}=0$ & 34.48 & 29.98 & $0.0134^{*}$ & 25.69 & 21.13 & $0.0106^{*}$ \\
$\mathrm{r} \leq 1$ & 8.78 & 15.49 & 0.3857 & 7.43 & 14.26 & 0.4394 \\
$\mathrm{r} \leq 2$ & 1.35 & 3.84 & 0.2449 & 1.35 & 3.84 & 0.2449 \\
\hline
\end{tabular}

Note: rstands for the hypothesized number of cointegrating relationships between export, import, and GDP; $\mathrm{H}_{0}: \mathrm{r}=0$ means that there is no cointegrating relationship betwen export, import and GDP. * indicates the rejection of the respective null hypotheses at $\alpha=0.05$ level of significance; the cointegration model is based on the vector autoregression model (VAR) with 1 lag as determined by the LRT, FPE, AIC, SIC, and HQ criteria; the critical values for Trace and Max-Eigenvalue statistics are calculated by EViews (10).

The results indicate that both the tests unanimously identified one cointegrating relationship among the export, import, and GDP at $\alpha=0.05$ level of significance. Thus, we conclude that there is one cointegrating relationship between the export, import, and GDP for India for the sample period. In other words, there exists a long run equilibrium relationship between the export, import, and GDP for India. 


\subsection{Granger Causality and Vector Error Correction Model (VECM)}

The empirical results from the Johansen and Juselius test for cointegration in 3.2 indicate that there is a cointegrating relationship between export, import, and GDP. This also means that a long run equilibrium relationship exists between the variables. We next move on to conduct the Granger causality test (Engle and Granger, 1987) under VECM framework. This test is a statistical procedure used to determine if one time series is helpful in forecasting another. VECM includes lags of the dependent variables, in addition to its own lags (Upadhyaya, Nag and Franklin Jr, 2018). In addition to indicating the direction of causality amongst the variables, the VECM also allows one to distinguish between short-run and long-run Granger causality relationships because it can capture both the short-run dynamics between time series and their long-run equilibrium relationship (Masih and Masih, 1996; Devkota and Panta (2018)).

Table 4. Granger Causality Results from Vector error correction model (VECM)

\begin{tabular}{ccccc}
\hline Response & \multicolumn{3}{c}{$\chi^{2}$ statistic } & \multirow{2}{*}{$E C T$} \\
\cline { 2 - 4 } & $\Delta$ Export & $\Delta$ Import & $\Delta \mathrm{GDP}$ & \\
\hline$\Delta$ Export & - & 0.15 & 0.12 & 1.33 \\
$\Delta$ Import & 0.04 & - & $6.68^{* *}$ & $-2.93^{* *}$ \\
$\Delta$ GDP & 1.464 & 0.004 & - & 1.35 \\
\hline
\end{tabular}

Note: $\Delta$ Export, $\Delta$ Import and $\Delta \mathrm{GDP}$ denote the first differences of the logarithmic values of the export, import, and the GDP respectively, $(* *)$ denotes the rejection of the null hypothesis at the $1 \%$ level of significance. Number of lags was selected as identified by using the LRT, HQ, AIC, SC, and HQ criteria.

We tested the long-run causality through the statistical significance of each of the error correction term (ECT) by an individual t-test, and the shortrun Granger causality through the significance of the lags of each explanatory variable by a Wald $\chi^{2}$ test. A variable $X_{t}$ is said to cause another variable $Y_{t}$ in the Granger sense if the one step ahead forecast of $Y_{t}$ in the regression model improves the quality of the model and/or forecasts by taking into account the historical values of $X_{t}$ (see, Din, 2004; Syczewska, 2014; and Osinska, 2011, for details). The results for both the long run and short run Granger causalities are reported quantitatively in Table 4, and then qualitatively in Table 5.

The results indicate that the coefficient of the error correction term of import variable is negative and statistically significant at the $1 \%$ level of significance. This implies that there are long run causalities running from GDP and export to import. Also, the chi-square statistic for the causality from GDP to import is statistically significant at the $1 \%$ level of significance. This suggests that there is a short run Granger causality running from GDP to import. It means that both the GDP and export Granger cause import in India. 
Table 5. Causality Results based on Vector Error Correction Model

\begin{tabular}{|c|c|c|c|c|}
\hline \multicolumn{2}{|c|}{ Causality } & \multirow[t]{2}{*}{ Short-Run } & \multirow[t]{2}{*}{ Long-Run } & \multirow[t]{2}{*}{ Direction of Causality } \\
\hline From & To & & & \\
\hline Export & GDP & No & No & None \\
\hline GDP & Export & No & No & \\
\hline Import & GDP & No & No & Unidirectional \\
\hline GDP & Import & Yes $^{* *}$ & Yes** & \\
\hline Export & Import & No & $Y_{e s}^{* *}$ & Unidirectional \\
\hline Import & Export & No & No & \\
\hline
\end{tabular}

Note: $* *$ denotes the rejection of the null hypothesis at the $1 \%$ level of significance; number of lags in the VECM was determined using the LRT, FPE, AIC, SIC, and HQ criteria.

The interpretations of the results of our study are straightforward. We have evidence of unidirectional causality running from GDP to import. This implies that an increase in economic growth increases power to purchase foreign goods and services. Similarly, we have evidence of unidirectional causality running from export to import. A possible explanation could be that when a country exports goods and services, it sells them to a foreign market which brings in money into the country. This money can then be used to purchase goods and services for the country.

The diagnostic testing of the estimated model (with the GDP as the dependent variable and export and import as independent variables) is performed using the residual analysis based on Breusch-Godfrey serial correlation LM test and the results are shown in table 6 . Under this test, the null hypothesis states that there is no serial autocorrelation of residuals. The chi-squared test statistic of 1.858151 with a p-value of 0.3949 suggests that the null hypothesis of no serial correlation is not rejected at the $1 \%$ level of significance, and thus confirms the adequacy of the model.

Table 6. Breusch-Godfrey serial correlation LM test results

\begin{tabular}{cccc}
\hline F-Statistic & 0.875485 & Prob F(2,84) & 0.4204 \\
Obs*R-Squared & 1.858151 & Prob Chi-Squared (2) & 0.3949 \\
\hline
\end{tabular}

\section{Conclusions and Discussion}

The present study investigated the causal relationships between the export, import, and GDP for India using the seasonally adjusted quarterly time series data for the period between 1996:Q2 and 2019:Q2.

The empirical results suggest that each of the export, import and GDP are non-stationary in their levels and are stationary in their first differences. In addition, the Johansen cointegration test suggests the existence of a long run equilibrium relationship between the variables. Finally, the Granger causality 
test based on VECM framework suggests the existence of unidirectional causal relationships from GDP to import, and from export to import. Thus, the sample data suggest that none of the ELG, GLE, and ILG hypotheses are valid for India.

Our finding of existence of long run equilibrium relationships between export, import, and economic growth for India is in line with Guntukula (2018) for India, Din (2004) for Bangladesh and Pakistan, and Moroke and Manoto (2015) for South Africa. However, our finding is contrary to Din (2004), who found no evidence of a long run equilibrium relationship between these variables for India, Nepal, and Sri Lanka. Also, our finding of the rejection of the ELG hypothesis is consistent to Mishra (2011) for India. However, this finding is contrary to the finding of Moroke and Manoto (2015) for South Africa, Awokuse (2007) for Bulgaria, and Guntukula (2018) for India. In addition, our finding of the rejection of the ILG hypothesis is contrary to the finding of Moroke and Manoto (2015) for South Africa and Awokuse (2007) for Poland. Finally, our findings of the rejection of the GLE hypothesis is contrary to the finding of Guntukula (2018) for India and Awokuse (2007) for Bulgaria.

We recognize, however, that this study only examined the impact of export and import on economic growth, thereby ignoring the myriad of other factors that also may affect the economic growth (Zang and Baimbridge, 2012). In addition, as Sharma and Dhakal (1994) mention, due to some limitations of the causality tests employed in this study, our results should be viewed with caution. Finally, as Ratanapakorn and Sharma (2007) rightly argue, one should use at least 30 years of data to run a cointegration test. Unfortunately, the unavailability of data led us to use only 24 years of quarterly data. Similar to those authors, our objective is to investigate a shorter timeperiod, and hence, the results should be viewed with some degree of caution.

\section{References}

Awokuse, T. O. (2008). Trade Openness and Economic Growth: Is Growth Export-led or Import-led? Applied Economics, 40(2), 161-173.

Alam, M., Uddin, G., \& Taufique, K. (2009). Import Inflows of Bangladesh: the Gravity Model Approach. International Journal of Economics and Finance (ISSN 1916-971X), 1(1), 131-139.

Balassa, B. (1978). Exports and Economic Growth: Further Evidence. Journal of Development Economics, 5(2), 181-189.

Bhagwati, J. N. (1978). Appendix to "Anatomy and Consequences of Exchange Control Regimes". In Anatomy and Consequences of Exchange Control Regimes, NBER, 219-221.

Bhagwati, J. N. (1988). Export-promoting Trade Strategy: Issues and Evidence. The World Bank Research Observer, 27-57. 
Devkota, M. L., \& Panta, H. (2018). An Inquiry into the Effect of the Interest Rate, Gold Price, and the Exchange Rate on Stock Exchange Index: Evidence from Nepal. Dynamic Econometric Models, 18, 49-65. https://doi.org/10.12775/DEM.2018.003

Dickey, D. A., \& Fuller, W. A. (1979). Distribution of the Estimators for Autoregressive Time Series with a Unit Root. Journal of the American Statistical Association, 74(366a), 427-431.

Dickey, D.A., \& Fuller, W.A. (1981). Likelihood Ratio Statistics for Autoregressive Time Series with a Unit Root. Econometrica, 1057-1072.

Din, M. U. (2004). Exports, Imports, and Economic Growth in South Asia: Evidence using a Multivariate Time-series Framework. The Pakistan Development Review, 105-124.

Engle, R. F., \& Granger, C. W. (1987). Co-integration and Error Correction: Representation, Estimation, and Testing. Econometrica, 251-276. https://doi.org/10.2307/1913236

Ghatak, S., \& Price, S. W. (1997). Export Composition and Economic Growth: Cointegration and Causality Evidence for India. Weltwirtschaftliches Archiv, (H. 3), 538-553.

Granger, C. W. (1981). Some Properties of Time Series Data and Their Use in Econometric Model Specification. Journal of Econometrics, 16(1), 121-130. https://doi.org/10.1016/0304-4076(81)90079-8

Guntukula, R. (2018). Exports, Imports and Economic Growth in India: Evidence from Cointegration and Causality Analysis. University of Hyderabad, India, 2(615), 221-230.

Johansen, S. (1988), Statistical Analysis of Cointegration Vectors, Journal of Economic Dynamics and Control, 12, 231-254, https://doi.org/10.1016/0165-1889(88)90041-3

Johansen, S. (1991), Estimation and Hypothesis Testing of Cointegration Vectors in Gaussian Vector Autoregressive Models, Econometrica, 59,1551-1580. https://www.jstor.org/stable/2938278

Johansen, S. (1992). Determination of Cointegration Rank in the Presence of a Linear Trend. Oxford Bulletin of Economics and Statistics, 54(3), 383-397. https://doi.org/10.1111/j.1468-0084.1992.tb00008.x

Johansen, S. \& Juselius, K. (1990), Maximum Likelihood Estimation and Inference on Cointegration - with Applications to the Demand for Money, Oxford Bulletin of Economics and Statistics, 52, 169-210. https://doi.org/10.1111/j.1468-0084.1990.mp52002003.x

Kogid, M., Mulok, D., Ching, K. S., Lily, J., Ghazali, M. F., \& Loganathan, N. (2011). Does Import Affect Economic Growth in Malaysia. Empirical Economics Letters, 10(3), 297-307.

Krugman, P. (1984). Import Protection as Export Promotion. Monopolistic Competition and International Trade.

Kumari, J. (2014). Export, Import and Economic Growth in India: A Study. The Indian Economic Journal, 62(3), 1157-1168.

Malhotra, M., \& Meenu (2009). Imports-growth Relationship in India: Causality Analysis. Indian Journal of Economics, 90(356), 33-46.

Masih, A. M., \& Masih, R. (1996). Energy Consumption, Real Income and Temporal Causality: Results from a Multi-country Study Based on Cointegration and Error-correction Modelling Techniques. Energy Economics, 18(3), 165-183.

Mazumdar, J. (2001). Imported Machinery and Growth in LDCs. Journal of Development Economics, 65(1), 209-224.

Michaely, M. (1977). Exports and Growth: An Empirical Investigation. Journal of Development Economics, 4(1), 49-53.

Mishra, P. K. (2011). The Dynamics of Relationship Between Exports and Economic Growth in India. International Journal of Economic Sciences and Applied Research, 4(2), 53-70. 
Mishra, P. K. (2012). The Dynamics of the Relationship between Imports and Economic Growth in India. South Asian Journal of Macroeconomics and Public Finance, 1(1), $57-79$.

Moroke, N. D., \& Manoto, M. (2015). How Applicable is Export-led Growth and Import-led Growth Hypotheses to South African economy? The VECM and Causality Approach. Journal of Governance and Regulation, 4(2), 15-25. http://dx.doi.org/10.22495/igr v4 i2 p2

Osińska, M. (2011), On the Interpretation of Causality in Granger Sense, Dynamic Econometric Models. http://dx.doi.org/10.12775/DEM.2011.009

Oxley, L. (1993). Cointegration, Causality and Export-led Growth in Portugal, 1985. Economics Letters, 43(2), 163-166.

Phillips, P. C., \& Perron, P. (1988). Testing for a Unit Root in Time Series Regression. Biometrika, 75(2), 335-346.

Ramos, F. F. R. (2001). Exports, Imports, and Economic Growth in Portugal: Evidence from Causality and Cointegration Analysis. Economic Modelling, 18(4), 613-23.

Ratanapakorn, O., \& Sharma, S. C. (2007). Dynamic Analysis between the US Stock Returns and the Macroeconomic Variables. Applied Financial Economics, 17(5), 69-377. https://doi.org/10.1080/09603100600638944

Sharma, S. C., \& Dhakal, D. (1994). Causal Analyses between Exports and Economic Growth in Developing Countries. Applied Economics, 26(12), 1145-1157.

Syczewska, E. M. (2014), The EURPLN, DAX and WIG20: The Granger Causality Tests Before and During the Crisis, Dynamic Econometric Models, 14, 93-104, http://dx.doi.org/10.12775/DEM.2014.005

Taghavi, M., Goudarzi, M., Masoudi, E., \& Gashti, H. P. (2012). Study on the Impact of Export and Import on Economic Growth in Iran. Journal of Basic and Applied Scientific Research, 2(12), 12787-12794.

Tang, C. F., Lai, Y. W., \& Ozturk, I. (2015). How Stable is the Export-led Growth Hypothesis? Evidence from Asia's Four Little Dragons. Economic Modelling, 44, 229-235.

Upadhyaya, K. P., Nag, R., and Mixon Jr, F. G. (2018). Stock Market Capitalization and the Macroeconomics of Transition Economies: The Case of India. Dynamic Econometric Models, 35-47. http://dx.doi.org/10.12775/DEM.2018.002

Weisberg, S. (2005). Applied linear regression (Vol. 528). John Wiley \& Sons.

Zang, W., \& Baimbridge, M. (2012). Exports, Imports and Economic Growth South Korea and Japan: A Tale of two Economies. Applied Economics, 44(3), 361-372.

Dynamic Econometric Models 19 (2019) 29-40 